\title{
Measuring the satisfaction gap in Management Education: A roadmap for achieving excellence
}

\author{
Ram Komal Prasad ${ }^{1}$, Sanjeev Verma ${ }^{2}$ \\ 1,2 NITIE Mumbai-400087, India
}

\begin{abstract}
This study aims to develop a deeper understanding of the management education in India and to uncover the constructs/factors that underlie the desired expectations to reveal the underlying satisfaction and the benefits that students look for. This paper focuses on identifying and evaluating techniques used to take on the challenges of quality improvement in management education. A questionnaire consisting of 43 items was developed to measure the constructs and its dimensions. The purpose of this work is to examine the performance of eight alternative measures of service quality of management education in India. The dimensions are as follows: Tangible aspects (5 items), Reliability (5 items), Competence (5 items), Industry Institute interaction (6 items), Course structure (6 items), Internship output (6 items), Employability (5 items) and Inculcation of Entrepreneurial spirit (5 items). The first draft of the questionnaire was subject to a pilot testing through a focus group and an expert evaluation. Data were gathered from 425 MBA students' effective sample from various institutes (mix of public, private and autonomous offering PGDM) located in Lucknow, North India. Structural equation modeling was used to test the management education service quality. Confirmatory factor analysis with partial disaggregation was performed on the eight dimensions of management education quality.
\end{abstract}

Keywords: Confirmatory factor analysis, Management education, Service quality

\section{Introduction:}

Service quality is an important feature of the literature in marketing and operations management which has started gaining attention in higher as well as professional education. Stern and Tseng (1993) reported that few higher institutions have adopted a service quality philosophy. Earlier research has demonstrated that students are reluctant to complain about poor service (Gronhaug and Arndt, 1980) but these days students are becoming increasingly more value conscious. The educational institutions in India, increasingly find themselves in an environment that is focused on understanding the role and importance of service quality. Relentless global, social, cultural and economic change is being translated by educational institutions into a continuous stream of complex reforms based on quality. There is a need for adaptation to serve the interests of its stakeholders in terms of greater responsiveness, responsibility, accountability and increased expectations etc. therefore educational systems are being pressurized to shift their focus from quantitative expansion, to an emphasis on quality. The quality of service experience becomes an important factor in buying decision (Baston, 1995).

Higher education quality assurance systems place emphasis on the student experience as one of the most important assessment criteria (Allen and Davis, 1991; Ramsden, 1991). In response to growing concerns from stakeholders about poor or inconsistent quality, institutions of higher education are increasingly realizing the significance of students centered philosophies and thereby, seeking ways to improve and provide better service to the students. Students' service could be viewed as a philosophy of management permeating throughout the institutions with the aim of satisfying the students through the quality of services. Educational institutions have begun to realize the importance of this philosophy, which is shown by an increasing concern among academics about the dissatisfaction of students regarding the quality of education and overall management of educational institutions. The educational literature suggests that there is mounting pressure from the students, parents, employers and even faculty members, to close the widening gap between their expectations of institutional performance and the actual performance (Brigham, 1994).

Quality in higher education exhibits all the classical features of services: it is intangible and heterogeneous, meets the criterion of inseparability by being produced and consumed at the same time, satisfies the perishability criterion and assumes the students participation in the delivery process (Cuthbert 1996a). Quality in services, with impact on students' psychology and resultant behavior which exhibits in terms of a positive attitude towards higher education services, has led to the conclusion that the quality is the single most important factor for long-term success and survival of educational institutions. Institutions have begun to realize the significance of a qualitative orientation and commensurate to this, there have been attempts at providing better services to the students.

This research investigation aims to analyze service quality among the sample of management graduate students of North India. Starting with the theoretical background, the paper outlines the results of a study conducted on the students as primary customers to obtain a perspective on service quality of select management 
institutions located in the region. Based on the literature review, followed by a pilot study, the various students' requirements were identified. The management educational services quality model was developed to identify the gap and determine the level of service quality in management institutes. Following this, use of structural equation modeling, confirmative factor analysis was set of minimum quality components that meet the requirements of the students as important customers. Therefore, it is imperative that educational institutes actively monitor the quality of their services and commit to continuous improvements in an effort to respond to the needs of enhancing the institutional image. A better understanding of how these students form impressions on quality which can provide valuable information to educational management for designing service delivery systems that enhance their satisfaction level (Seymour, 1992).

\section{Service quality: Conceptualization and measurement}

The conceptualization of service quality has aroused considerable interest and debate in the research literature because of the difficulties in both defining and measuring it and there is no consensus emerging on either (Parasuraman et al., 1985; Dotchin \& Oakland, 1994; Gaster, 1995; Asubonteng al., 1996). A definition of 'service quality' is person dependent and has different meaning for different people. Most definitions of service quality are customer- centered (Galloway \& Wearn, 1998), with customer satisfaction being seen as functions of perceived quality (Anderson \& Sullivan, 1993), or perceived quality being a function of customer satisfaction (Parasuraman et al., 1988). Thus, the commonly accepted orientation defines service quality as the extent to which a service meets customers' needs or expectations (Lewis \& Mitchell, 1990; Dotchin \& Oakland, 1994; Asubonteng et al., 1996). Service quality, as perceived by customers, involves a comparison of what they feel the service should be (expectation, E) with their judgment of the services they received (perception, P) (Sasser \& Arbeit, 1978; Gronroos, 1984; Parasuraman et al., 1985; Zeathaml et al., 1985). It is defined as the difference between customer expectations of service and perceived service. If expectations are greater than performance, then perceived quality is less than satisfactory and hence customer dissatisfion occurs (Parasuraman et al., 1985; Lewis \& Mitchell, 1990).

\section{Measuring service quality}

To achieve quality as perceived by the customer, proactive organizational commitment is required. Berry (1995) suggests that service plays an important role in enhancing value, and can positively influence a firm's success. From a customer perspective, a provider's service can help to offset potential burdens, like frustration, repentation, high price etc. As a result, understanding and measuring customer expectations and performance are therefore an essential component that can be used to enhance organisation's service provision.

In analyzing service from the customer's perspective, researches by Parasuraman et.al (1988) yielded a useful concept of ten potentially overlapping dimensions. When developing their framework further, extensive statistical analysis revealed significant correlations between certain dimensions depicted in the original concept, and this led to the regrouping of the original ten items into five subsequent dimensions (tangibles, reliability' responsiveness, assurance and empathy) were labeled as the SERVQUAL scale. The instrument represents a multi-item scale that since its development has been widely used for measuring consumer expectations and perceptions of service quality. It consists of 22 parallel expectation (E) and perception (P) statements on five service quality dimensions. In order to obtain view for the statement, consumers are required to select a response on 7 point Likert scales that range from strongly disagree to strongly agree. This then allows for the difference in scores for each dimension which has been calculated. The difference $(\mathrm{P}-\mathrm{E}=\mathrm{Q})$ represents the measure of service quality $(\mathrm{Q})$. Where $\mathrm{Q}$ is negative, a service gap exists. However, if $\mathrm{Q}$ is positive, customer expectations are being exceeded.

In the present research an instrument was designed which provides the measurement of the relative importance associated with each dimension on management education. After the mean for each dimension has been calculated, the relative importance score and weighted average score was calculated for each dimension. The instrument was developed with the intention that it could be applied in measuring the quality of services of management education in the broad framework of research investigations.

\section{Service quality in higher education}

Service quality in higher education is relative concept, with respect to the stakeholders in higher education and circumstances in which it is involved. In other words, quality means different things to different people as well as person may adopt different conceptualizations at different moments (Zafiropoulos et al.2005). However, Sahney et al. 2004 highlighted that definitions of quality in education follow the general definitions of quality. The applicability of service quality in the educational sector attracted the interest of many theorists and researcher (Edwell, 1993; Sherr \& Lozier, 1991; Tribus, 1994; Brigham, 1993). Educational institutions are perceived as organizations designed to transform teaching, curriculum, organizational and management education processes in a way which serves students interests for their career. Substantial interest in service 
quality in management education has begun to emerge (Sallis, 1993), and this interest has been focused primarily on higher educational institutes Coate, 1990; Cope \& Sherr, 1991; Masters \& Leiker, 1992; Saunders \& Walker, 1991; Sutcliffe \& Polock, 1992; Van Vught \& Westerheijden, 1992; Winter,1991). As with other services, the concept of quality when applied to higher education has been inclusive (Williams, 1990; Staropli, 1992; Liaison committee of records' conferences, 1993; Cheng \& Tam, 1997) and service quality in higher education has been defined variedly as, excellence in education (Peters \& Waterman, 1982), value in addition(Feigenbaum,1951), fitness for purpose (Reynolds,1986; Brennan et al.,1992; Tang \& Zairi,1998), fitness of educational outcome and experience for use (Juran \& Gryna,1998), conformance of education output to planned goals, specifications and requirements (Gilmore, 1974; Crosby, 1979), defect avoidance in education process ( Crosby, 1979), and meeting or exceeding customer's expectations of education ( Parasuraman et al. 1985).

Quality initiatives have been the subject of enormous amount of discourse to practitioner and academicians, and various levels have been found as a gateway into higher education (Avdjieva \& Wilson, 2002). Many academic institutions have implemented such policies in response to a reduction in student funding, complaints by employers and parents, as well as the pioneering success of such drivers in many corporate businesses (Kanji and Tambi, 199). However, since the early to mid 1990s a stream of work has explored various aspects of service quality relating to the teaching and learning factors, and the environmental attributes influencing higher education (Harrop \& Douglas, 1996; Narasimhan, 1997; and Shank et al. 1995), with the majority of such investigations using students' evaluations to assess quality (Rowley, 1997; Aldridge \& Rowley, 1998). It may be concluded that service quality in higher education is a multiple concept with varying conceptualizations and this poses problems in formulating a single, comprehensive definition. It concludes within its ambit the quality of inputs in the form of students, faculty, support staff and infrastructure; the quality of processes in the form of learning and teaching activity; and the quality of outputs in the form of the enlightened students.

\section{Gap analysis in higher education}

Gap analysis is not new in higher educational context, and a number of studies have been influenced by the work of Parasuraman et al. For example, (Long et al.,1999) 'gap analysis' to develop a number of questions in order to compare what students 'look for'(expect) and what they 'experience' on a course. (Sander al., 2000) meanwhile examined undergraduates' expectations and preferences in teaching, learning and assessment. LaBay \& Comm 2003 also developed a number of measures to evaluate students' expectations and perceptions, concerning their faculty members, on a sample of undergraduate students.

Customers judge the desired quality according to their expectations (Ghobadian et al., 1994; Dotchin \&Oakland, 1994: Kandampully, 1997; Fergueson et al., 1999, Lee et al., 2000; Walter \& Germunden, 2000). The ultimate measure of quality is whether or not the product or service lives up to expectations of the customers. The most widely used and tested service quality instrument 'SERVQUAL' based on the service quality 'gap model' (Parasuraman et al.,1988,1991,1993,1994), which defines service quality as a function of gap between customers' expectations of a service and their perceptions of the actual service delivery by organization. In brief, SERVQUAL is recognized as a tried and tested instrument that has been successfully applied in many different service contexts (Buttle, 1996). Its strengths more than outweigh any deficiencies, and the results can be presented in a format useful for targeting specific service improvements (O'Neill \& Palmer, 2001). Over recent years the higher education sector has become more quality conscious, which has been fuelled by increasing competition, a reduction in state funding, and greater consumer demands (Ford et al., 1999; Kanji \& Tambi, 1999). In response, a growing number of institutions and academics have grappled with such quality issues and have undertaken research with the aim of addressing some of the key concerns (Lau, 2003; Oldfield \& Baron, 2000).

This research therefore aims to bridge this gap, by using a modified SERVQUAL instrument to investigate service quality among management graduate students studying in North India. However, for this study the terminology has been borrowed, the items that these dimensions contained have been changed to adapt to the needs of management educational service and few other dimensions have also been added.

\section{The conceptual model}

As to higher education in India in the present study, eight dimensions which composed distinct components of perceived service quality has been taken as factor determining the quality of management education. On these eight factor dimensions, 43 items were taken into consideration. The reliability of each factor dimension was checked and found $\alpha$ value above .60 and thus the instrument has been highly reliable and used for further process 


\section{Figure-1: Perceived service quality model}

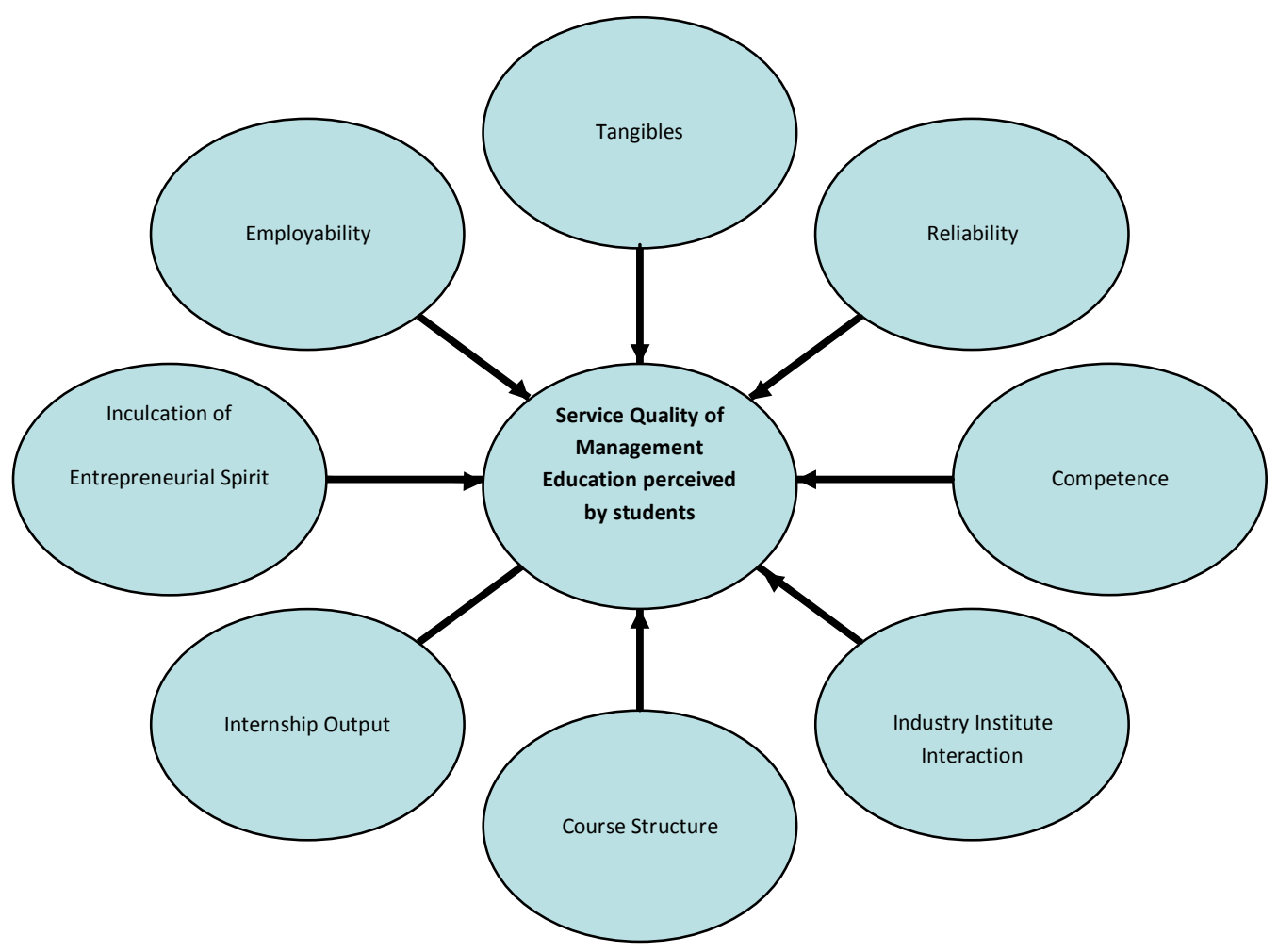

Physical aspects: This pertains to the institute's physical facilities, equipment, support services and attraction of campus. Since students do not receive only education service, but also a large component of support service, they undoubtedly depend on other cues in the absence of physical aspects evidence by which to assess service quality.

Reliability: This refers to the colleges' ability to perform the promised service dependably and accurately.

Competence: It refers to the faculties' intrinsic characters which are formed by the accumulation in long teaching history and learning and construct from working base of a good teacher.

Industry Institute Interaction: This means the interaction level of student and institute with the industry through industrial visits, interaction with industry experts, executive interaction and industrial exposure etc.

Course structure: It mainly refers to what will be taught to the students and the detailed requirements of it as the industry demand.

Internship output: It mainly refers to the experience of student during internship and their interaction with the working group. It also concerns to the expertise gained and possibility of getting employed in the organization of internship.

Inculcation of Entrepreneurial Spirit: It refers to the spirit of starting/establishing business venture among management graduates. It also refers to the innovation and risk taking ability and converting risk into profit.

Employability: It refers to the skills, knowledge, competence etc. that is required to be employed in an organization of repute.

\subsection{Sampling and Data collection}

\section{Research Methodology}

We solicited anonymous response to questionnaire given to management students of management institutes. Questionnaires were administered during the last week of March 2012. Questionnaires were hand delivered to all students studying final year MBA/PGDM course. Four hundred twelve students response were collected who participated from various management institutes. Students were given verbal instructions, and completed the questionnaire in twenty minutes resulting 69 percent actual response rate.

\subsection{Measure Instrument}

The literature review along with interaction held with faculty members provided the basis for constructing this conceptual model and for developing the questionnaire used in this study. The survey 
instrument contained 43 variables related to different dimensions of the university/institute educational service offering. Items pertaining to service quality assessment were measured on a 7 point Likert scale $(1=$ strongly disagree to $7=$ strongly agree). The information gathered was analyzed using the factor analysis and multiple regression techniques. The factor analysis allowed us to identify the dimensional structure of perceived service quality. Then, the regression analysis allowed us to identify the more important dimensions. Confirmatory factor analysis was also used to validate the factor structure founded with exploratory factor analysis and to asses convergent and discriminant validity of the instrument.

\section{Data Analysis and interpretation}

The next step of management education regarding service quality evaluation is to collect the results of our questionnaire, and adopt various statistical methods to analyze the data.

Table-1: Mean score (Standard deviation) for modified SERVQUAL dimensions

\begin{tabular}{|c|c|c|c|c|}
\hline S.No. & Items & P (Std. D) & E (Std. D) & P-E \\
\hline \multicolumn{5}{|c|}{ Physical Aspects } \\
\hline 1 & Modern-looking equipment & $4.23(1.90)$ & $6.11(1.24)$ & -1.88 \\
\hline 2 & Visually appealing & $4.39(1.78)$ & $5.80(1.18)$ & -1.41 \\
\hline 3 & Support services like Library, Computer lab etc. & $4.75(1.80)$ & $6.28(1.14)$ & -1.53 \\
\hline 4 & Neat cleaned, attractive and convenient & $4.78(1.81)$ & $6.67(6.22)$ & -1.89 \\
\hline 5 & Sufficient physical equipment & $4.45(1.74)$ & $5.91(1.21)$ & -1.46 \\
\hline \multicolumn{5}{|c|}{ Reliability } \\
\hline 6 & Deliver service on time & $4.53(1.86)$ & $5.81(1.37)$ & -1.28 \\
\hline 7 & Ability to solve complains & $4.69(1.88)$ & $5.96(1.34)$ & -1.27 \\
\hline 8 & Perform right the first time & $4.55(1.75)$ & $5.81(1.10)$ & -1.26 \\
\hline 9 & Promises to do something by a certain time & $4.53(1.84)$ & $5.63(1.24)$ & -1.10 \\
\hline 10 & Solving the problems of students & $4.74(1.87)$ & $5.77(1.63)$ & -1.03 \\
\hline \multicolumn{5}{|c|}{ Competence } \\
\hline 11 & Sufficient faculty/support staff & $5.10(1.64)$ & $6.15(1.24)$ & -1.05 \\
\hline 12 & Experienced faculty & $5.15(1.66)$ & $6.27(1.10)$ & -1.12 \\
\hline 13 & Theoretical knowledge and adequate qualification & $5.32(1.54)$ & $6.27(1.09)$ & -0.95 \\
\hline 14 & Mastery of academic knowledge & $5.18(1.54)$ & $6.15(1.08)$ & -0.97 \\
\hline 15 & Refresher course and FDP & $5.04(1.70)$ & $5.88(1.33)$ & $-0,84$ \\
\hline \multicolumn{5}{|c|}{ Industry Institute interaction } \\
\hline 16 & Industry expert to deliver lecture & $4.57(1.97)$ & $6.23(1.07)$ & -1.66 \\
\hline 17 & Work on industry project & $4.33(1.93)$ & $6.22(1.09)$ & -1.89 \\
\hline 18 & Annual industrial visit & $4.56(2.18)$ & $6.39(0.95)$ & -1.83 \\
\hline 19 & Industrial proposal and students involvement & $4.17(2.05)$ & $5.90(1.34)$ & -1.73 \\
\hline 20 & Establishing Industry Institute Partnership Cell & $3.95(2.05)$ & $5.96(1.27)$ & -2.01 \\
\hline 21 & Short term on the job training & $4.12(2.02)$ & $6.19(0.98)$ & -2.07 \\
\hline \multicolumn{5}{|c|}{ Course structure } \\
\hline 22 & Update syllabus time to time & $4.76(1.85)$ & $6.38(1.04)$ & -1.62 \\
\hline 23 & Designs relevant course curriculum & $4.85(1.68)$ & $6.32(0.94)$ & -1.47 \\
\hline 24 & Encourages teamwork and communication skill & $4.87(1.74)$ & $6.42(0.86)$ & -1.55 \\
\hline 25 & Computer as integral part of the syllabus & $5.60(5.46)$ & $6.38(0.81)$ & -0.78 \\
\hline 26 & Course contains basic knowledge \& skill & $5.03(1.60)$ & $6.27(0.81)$ & -1.24 \\
\hline 27 & Industrial and managerial case studies & $5.04(1.63)$ & $6.26(1.00)$ & -1.22 \\
\hline \multicolumn{5}{|c|}{ Internship output } \\
\hline 28 & Support on internship project & $4.56(2.07)$ & $6.15(1.13)$ & -1.59 \\
\hline 29 & Learning opportunity during internship & $4.70(1.92)$ & $6.24(0.82)$ & -1.54 \\
\hline 30 & Employment probability & $4.40(1.86)$ & $3.95(1.09)$ & 0.45 \\
\hline 31 & Experience, expertise and exposure & $4.60(1.81)$ & $6.07(1.17)$ & -1.47 \\
\hline 32 & Conformity between interest and task allotted & $4.72(1.80)$ & $6.03(1.23)$ & -1.31 \\
\hline 33 & Knowledge and employability & $4.92(1.85)$ & $6.12(0.97)$ & -1.20 \\
\hline \multicolumn{5}{|c|}{ Inculcation of Entrepreneurial Spirit } \\
\hline 34 & Inculcation of entrepreneurial spirit & $4.42(1.71)$ & $5.92(1.10)$ & -1.50 \\
\hline 35 & Implantation of entrepreneurial seed & $4.54(1.81)$ & $6.05(1.06)$ & -1.51 \\
\hline 36 & Entrepreneurial spirit after course completion & $4.54(1.76)$ & $6.07(1.10)$ & -1.53 \\
\hline 37 & Entrepreneurs' demonstration of managerial skill & $4.56(1.95)$ & $6.19(1.02)$ & -1.63 \\
\hline
\end{tabular}


Measuring the satisfaction gap in Management Education: A roadmap for achieving excellence

\begin{tabular}{|l|l|l|l|l|}
\hline 38 & Knowledge refinement & $4.73(1.80)$ & $6.25(0.93)$ & -1.52 \\
\hline Employability & & & \\
\hline 39 & Campus placement & $5.11(1.80)$ & $6.50(0.82)$ & -1.39 \\
\hline 40 & Employability enhancement & $4.96(1.55)$ & $6.42(0.84)$ & -1.46 \\
\hline 41 & Employment confidence & $4.94(1.56)$ & $6.24(0.97)$ & -1.30 \\
\hline 42 & Academic value addition & $4.93(1.57)$ & $6.14(1.09)$ & -1.21 \\
\hline 43 & Dividend on investment & $4.90(1.61)$ & $6.28(0.87)$ & -1.38 \\
\hline \multicolumn{2}{|l|}{ Totals } & 202.81 & 262.01 & -59.2 \\
\hline Average & 4.71 & 6.09 & -1.71 \\
\hline
\end{tabular}

The mean scores from the sample are illustrated in Table -1. For each statement the mean Expectation (E) and Perception $(\mathrm{P})$ values, along with a service quality value from the formula are presented, $\mathrm{Q}=\mathrm{P}-\mathrm{E}$ (Parasuraman et al., 1988). The three columns provide summary results for the institution service quality, and the overall SERVQUAL results are illustrated in Table -1, above the three columns. Where the gap $(\mathrm{P}-\mathrm{E})$ is negative, this refers to perceptions of the institution falling short against initial students' expectations, and the presence of service quality gaps. The findings suggest a short fall on all the items measured. The expectation and perception items were measured using a seven point Likert scale, from $1=$ strongly disagree, to $7=$ strongly agree, with 4 serving as a mid point/neutral opinion on the scale. Mean scores greater than four identify a tendency for respondents to agree with a particular statement, whereas means of less than four indicate disagreement.

\section{Expectations (E)}

It can be concluded (Tables -1) that expectation (E) values among the North Indian management graduate students were higher (means ranging from 5.63 to 6.67). Thirty one statements $(1,3,4,11,12,13,14,16,1718,21,22,12,24,25,26,27,28,29,31,32,33,35,36,37,38,39,40,41,42$ and 43$)$ illustrate mean scores of 6.03 to 6.67 . This suggests that Indian graduate students really have higher expectations in terms of need for all the items covering these thirty one statements.

\section{Perceptions (P)}

Only one perception items (20 items) is below the mid-point 4 on the scale, suggesting that there is disagreement among students in terms Industry institute partnership cell of the institution. More over most of the items exceeded from 4.12 to 5.60 suggesting that the sample had a tendency to agree that sufficient items have given adequate perception among the students.

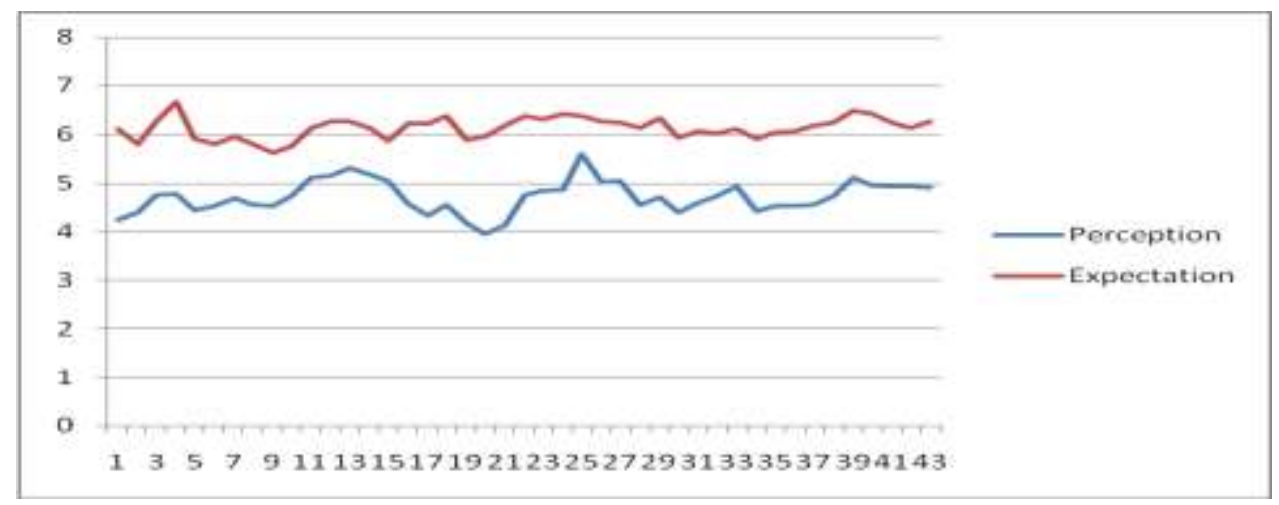

Figure-2: Gap analysis of perception and expectation

\subsection{Service Quality Gaps Analysis (P-E)}

The service quality gaps are demonstrated in the third column of Table -1. As each item except item30 (probability of employment) has a negative value, students' perceptions of the service are falling short of their expectations. In the sixth factor Internship Output, item 30 the employment probability in organization of internship is positive (0.45) represents that the students have higher perception on it. Paired sample t-tests were also undertaken on the perception and expectation mean items, in order to identify whether or not statistically significant service quality gaps were apparent. Findings from data presented in Table- 2 demonstrate significant differences of P-E value between management students' perceptions and expectations of service on all 43 statements in North India. It can be concluded that there is a significant difference between the students' expectations and perceptions at the $95 \%$ confidence level. However, for all the other statements, there is a statistical significance of a 0.01 , which illustrates a statistically significant gap between the students' 
perceptions and expectations of service at the $99 \%$ confidence level. These represent service quality gaps that the institution should take the appropriate measures on-board to bridge.

Table-2: One sample test statistics

\begin{tabular}{|c|c|c|c|c|}
\hline S.No. & Items & \multicolumn{2}{|c|}{$\mathbf{P} \quad \mathbf{E}$} & \multirow{2}{*}{$\begin{array}{l}(\mathrm{P}-\mathrm{E}) \\
\text { value }\end{array}$} \\
\hline \multicolumn{2}{|c|}{ Physical Aspects } & Percep & Expect & \\
\hline 1 & Modern-looking equipment & 26.58 & 56.80 & -30.22 \\
\hline 2 & Visually appealing & 28.44 & 56.55 & -28.11 \\
\hline 3 & Support services like Library, Computer lab etc. & 30.40 & 63.29 & -32.89 \\
\hline 4 & Neat cleaned, attractive and convenient & 30.46 & 12.36 & +18.10 \\
\hline 5 & Sufficient physical equipment & 29.38 & 55.99 & -26.61 \\
\hline \multicolumn{5}{|c|}{ Reliability } \\
\hline 1 & Deliver service on time & 28.18 & 48.80 & -20.62 \\
\hline 2 & Ability to solve complains & 28.78 & 51.28 & -22.50 \\
\hline 3 & Perform right the first time & 29.85 & 61.08 & -31.23 \\
\hline 4 & Promises to do something by a certain time & 28.28 & 44.83 & -16.55 \\
\hline 5 & Solving the problems of students & 29.40 & 40.82 & -11.42 \\
\hline \multicolumn{5}{|c|}{ Competence } \\
\hline 1 & Sufficient faculty/support staff & 35.82 & 56.91 & -21.09 \\
\hline 2 & Experienced faculty & 35.72 & 65.62 & -29.90 \\
\hline 3 & Theoretical knowledge and adequate qualification & 39.86 & 66.04 & -26.18 \\
\hline 4 & Mastery of academic knowledge & 38.63 & 65.39 & -26.76 \\
\hline 5 & Refresher course and faculty development programme & 34.03 & 50.85 & -16.82 \\
\hline \multicolumn{5}{|c|}{ Industry Institute Interaction } \\
\hline 1 & Industry expert to deliver lecture & 26.70 & 67.03 & -40.33 \\
\hline 2 & Work on industry project & 25.86 & 65.36 & -39.50 \\
\hline 3 & Annual industrial visit & 24.11 & 77.43 & -53.32 \\
\hline 4 & Industrial proposal and students involvement & 23.42 & 50.72 & -27.30 \\
\hline 5 & Establishing Industry Institute Partnership Cell & 22.22 & 54.08 & -31.86 \\
\hline 6 & Short term on the job training & 23.51 & 74.29 & -50.78 \\
\hline \multicolumn{5}{|c|}{ Course structure } \\
\hline 1 & Update syllabus time to time & 29.65 & 70.62 & -40.97 \\
\hline 2 & Designs relevant course curriculum & 33.17 & 76.77 & -43.60 \\
\hline 3 & Encourages teamwork and communication skill & 32.16 & 85.75 & -53.59 \\
\hline 4 & Computer as integral part of the syllabus & 11.82 & 90.44 & -78.62 \\
\hline 5 & Course contains basic knowledge \& skill & 36.15 & 88.44 & -52.29 \\
\hline 6 & Industrial and managerial case studies & 35.54 & 71.74 & -36.20 \\
\hline \multicolumn{5}{|c|}{ Internship output } \\
\hline 1 & Support on internship project & 25.40 & 62.68 & -37.28 \\
\hline 2 & Learning opportunity during internship & 28.18 & 86.87 & -58.69 \\
\hline 3 & Employment probability & 27.21 & 62.82 & -35.61 \\
\hline 4 & Experience, expertise and exposure & 27.25 & 59.69 & -32.44 \\
\hline 5 & Conformity between interest and task allotted & 30.14 & 56.51 & -26.37 \\
\hline 6 & Knowledge and employability & 30.65 & 72.67 & -42.02 \\
\hline \multicolumn{5}{|c|}{ Inculcation of Entrepreneurial Spirit } \\
\hline 1 & Inculcation of entrepreneurial spirit & 29.76 & 61.82 & -32.06 \\
\hline 2 & Implantation of entrepreneurial seed & 28.83 & 65.78 & -36.95 \\
\hline 3 & Entrepreneurial spirit after course completion & 29.60 & 63.39 & -33.79 \\
\hline
\end{tabular}


Measuring the satisfaction gap in Management Education: A roadmap for achieving excellence

\begin{tabular}{|l|l|l|l|l|l|}
\hline 4 & Entrepreneurs' demonstration of managerial skill & 26.78 & 69.64 & -42.86 \\
\hline 5 & Knowledge refinement & 30.34 & 77.56 & -47.22 \\
\hline Employability & \multicolumn{3}{|l|}{} & \multicolumn{3}{|l|}{} \\
\hline 1 & Campus placement & 32.69 & 91.21 & -58.52 \\
\hline 2 & Employability enhancement & 36.82 & 87.58 & -50.76 \\
\hline 3 & Employment confidence & 36.38 & 73.57 & -37.19 \\
\hline 4 & Academic value addition & 36.06 & 64.69 & -28.63 \\
\hline 5 & Dividend on investment & 35.13 & 82.81 & -47.68 \\
\hline
\end{tabular}

IX. Dimensionality

Both exploratory and confirmatory factor analysis were used to asses the dimensionality of the service quality measure. During the course of analysis, the service quality scales were refined to produce an optimal set of items. Table-3 presents the items and the factor loadings from a principal component analysis with varimax rotation which is a tried and tested method that frequently yields a simple structure (Norman \& Streiner, 1997). The factor program extracted eight factors with an eigenvalue greater than 1.00 and the factors accounting for a minimum $60 \%$ of the variance.

Table-3: Factor loading matrix following varimax rotation

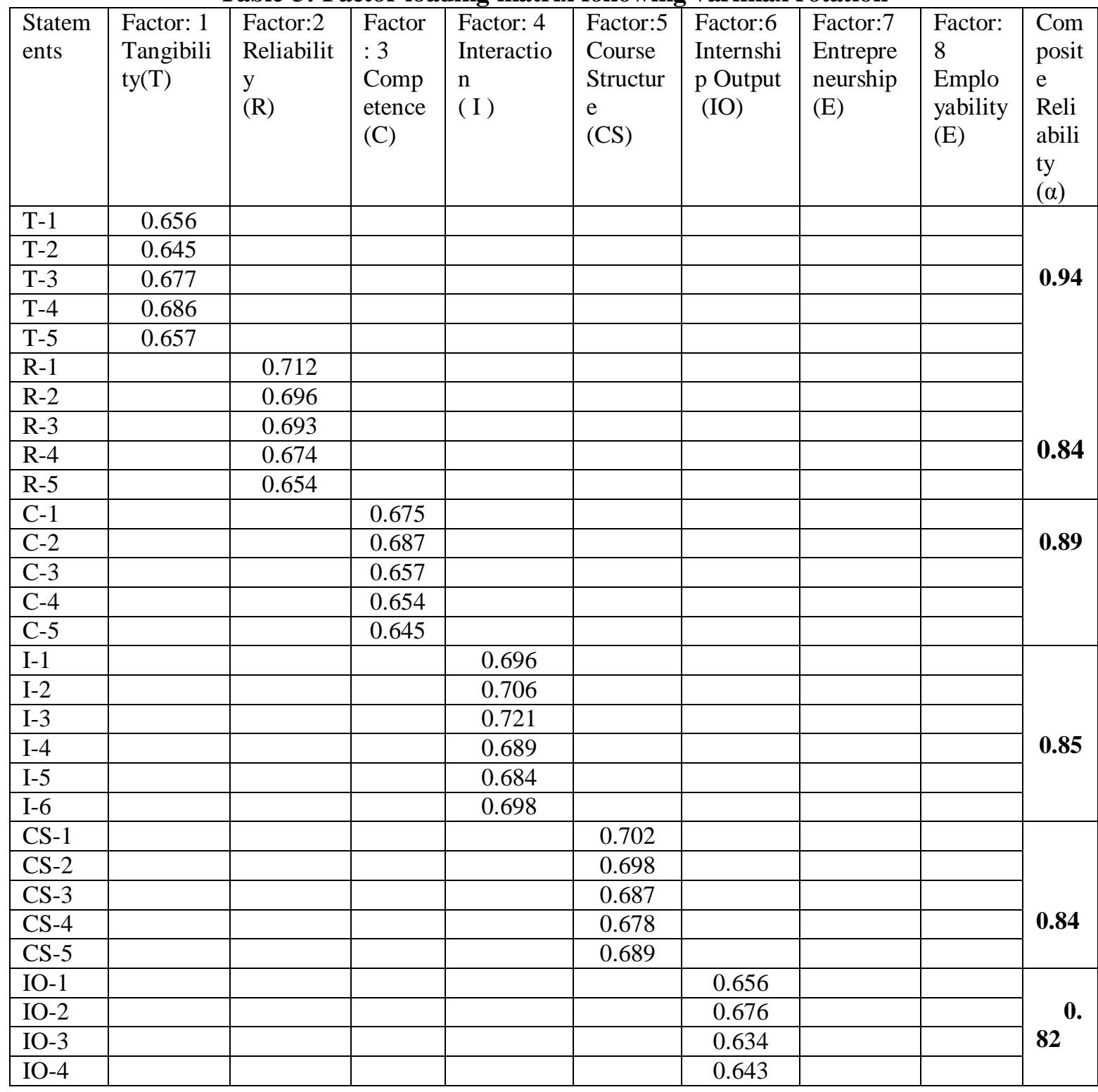


Measuring the satisfaction gap in Management Education: A roadmap for achieving excellence

\begin{tabular}{|c|c|c|c|c|c|c|c|c|c|}
\hline IO-5 & & & & & & 0.675 & & & \\
\hline E-1 & & & & & & & 0.623 & & \multirow{6}{*}{0.90} \\
\hline E-2 & & & & & & & 0.632 & & \\
\hline E-3 & & & & & & & 0.643 & & \\
\hline E-4 & & & & & & & 0.614 & & \\
\hline E-5 & & & & & & & 0.653 & & \\
\hline E-6 & & & & & & & 0.654 & & \\
\hline EP-1 & & & & & & & & 0.676 & \multirow{5}{*}{0.78} \\
\hline EP-2 & & & & & & & & 0.657 & \\
\hline EP-3 & & & & & & & & 0.609 & \\
\hline EP-4 & & & & & & & & 0.654 & \\
\hline EP-5 & & & & & & & & 0.643 & \\
\hline $\begin{array}{l}\text { Eigen } \\
\text { Val. }\end{array}$ & 2.534 & 2.724 & 2.108 & 2.902 & 1.331 & 2.290 & 1.509 & 4.113 & \\
\hline $\begin{array}{l}\text { Variati } \\
\text { on } \\
\text { Explai } \\
\text { ned }\end{array}$ & 6.829 & 7.338 & 5.903 & 7.748 & 3.096 & 6.327 & 4.509 & 10.565 & \\
\hline $\begin{array}{l}\text { Cum.V } \\
\text { aria. }\end{array}$ & 6.829 & 14.167 & 20.070 & 27.818 & 30.914 & 37.241 & 41.750 & 52.315 & \\
\hline
\end{tabular}

Few items were eliminated from the scale because they performed poorly in the analysis. Specifically, they had low factor loadings or they had no clear loading on a particular factor. There are eight factors each having Eigen value exceeding one for management education institution. The 43 items were subjected to EFA and eight factors model was estimated. The resulting scale was composed of all eight items. The eight-factor solution accounted for $52.315 \%$ of the total variance, and exhibited a KMO measure of sampling adequacy of 0.839 . The Cronbach alpha figures suggest that the items represent reliable measures for each of the eight dimensions and thus support the instrument. The resultant empirical factor structure indicated that factor combined to form a first factor while some other factors like Industry institute interaction, tangibility etc. the second, third and fourth factor respectively.

\section{Confirmatory factor analysis}

Confirmatory factor analysis was conducted to assess dimensionality. The raw data was used to as input in the analysis. Confirmatory factor analysis with partial disaggregation was performed on the eight dimensions of management education institutes. The partial disaggregation technique was applied instead of the traditional structural equation approach (or total disaggregation) although the traditional disaggregation technique provides the model detailed analysis for construct testing (each item is used as a separate indicator of the relevant constructed), it has a tendency to be cumbersome due to potentially high levels of random error in typical items and the many parameters that must be estimated. In contrast, partial disaggregation allows one to proceed with meaningful research by combining items into composites to reduce higher levels of random error and yet it retains all the advantages of structural equations, including accounting for measurement error, allowing for multiple, multidimensional variables and testing for hierarchal factor structures. To operationalize partial disaggregation in this study, items that relate to a given construct (factors/dimension) were combined to create two composite indicators for each construct instead of several single-item indicators. The chi-square is a badness-of-fit measure in the sense that a small chi-square corresponds to good fit and a large chi-square to bad fit. A number of fit measures that take particular account of the error of approximation in the population and the precision of the fit measure itself have been proposed (Browne \& Cudeck, 1993). The Root Mean square Error of Approximation (RMSEA) is suggested to be used as a measure of discrepancy per degree of freedom (Browne \& Cudeck, 1993; Steiger, 1990).the lower the RMSEA values; the better it is, with maximum acceptable values between 0.08 and 0.09 . Further, to eliminate or reduce the dependence of chi-square on sample size, the values of the Goodness-of-Fit (GFI) and Adjusted Goodness-of-Fit (AGFI), Tucker Lewis index (TLI), Comparative fit index (CFI) and Normalized fit index (NFI) were used. The score obtained from the analysis suggested an excellent fit between the data and the model. All the fit indices comply with the values recommended by Heir et al.(1998) and Arbuckle and Worthke (1995). The finding indicates that the perceived service quality is multidimensional construct that can be measured with a scale composed of eight dimensions. 
Measuring the satisfaction gap in Management Education: A roadmap for achieving excellence

Table- 4: Fit Statistics in the structural Equation Model

\begin{tabular}{|c|l|c|c|}
\hline S.No. & \multicolumn{1}{|c|}{ Goodness- of -fit model index } & $\begin{array}{c}\text { Recommended } \\
\text { value }^{*}\end{array}$ & $\begin{array}{c}\text { Management } \\
\text { education model }\end{array}$ \\
\hline 1. & Chi-square/degree of freedom & $\leq 2.00$ & 2.363 \\
\hline 2. & Goodness-of-index (GFI) & $\geq 0.90$ & 0.873 \\
\hline 3. & Adjusted goodness-of-index (AGFI) & $\geq 0.90$ & 0.832 \\
\hline 4. & Tucker -Lewis index (TLI) & $\geq 0.90$ & 0.910 \\
\hline 5. & Comparative fit index (CFI) & $\geq 0.90$ & 0.942 \\
\hline 6. & Normalized fit index (NFI) & $\geq 0.90$ & 0.952 \\
\hline 7. & $\begin{array}{l}\text { Root mean square of approximation } \\
\text { (RMSEA) }\end{array}$ & $\leq 0.80$ & 0.079 \\
\hline
\end{tabular}

*These criteria are according to Arbuckle and Worthke (1995) and Hair et al (1998)

**Segars And Grower (1993) recommended chi-square/degree of freedom value of $\leq 3.00$

\section{Internal consistency and validity}

Internal consistency was measured by computing Cronbach's alpha for each multi-item scale. Reliability coefficients were uniformly above the recommended level of 0.08(Nunnally, 1978) and compare well with reported alpha coefficients in the service quality literature (Morales et al., 1998) and in consumer research (Peterson, 1994). Construct reliabilities were computed for the overall scale as well as at the dimension level. The results of the test indicated that the modified SERVQUAL model is a very much reliable instrument, registering an overall Cronbach alpha value of 0.972 . Hence, the internal consistency reliabilities of the measures used in this study were all acceptable. Next, the validity of the instrument is assessed using two methods; content validity and discriminant validity. Content validity refers to the degree which an instrument covers the meaning of the concepts included in a particular research (Babbie, 1992). For this study, the content validity of the proposed instrument is adequate enough because the instrument has been carefully constructed, supported by an extensive literature review. Now, we also endeavored to test the discriminant validity of this instrument. Discriminant validity gauges the extent to which measures of two different constructs are comparatively distinctive from each other, and that their correlation values are neither absolute 0 nor 1 (Campbell and Fiske 1959). A correlation analysis was run on all the dimensions management education and the results are presented in the following Table-5. It is found that all the dimensions are not perfectly correlated as their correlation coefficients fall between 0 and 1 , hence establishing the discriminant validity of the higher education service quality model.

Table 5: Correlation results

\begin{tabular}{|l|c|c|c|c|c|c|c|c|}
\hline Dimensions & $\begin{array}{l}\text { Tangi } \\
\text { bility }\end{array}$ & $\begin{array}{l}\text { Reliab } \\
\text { ility }\end{array}$ & $\begin{array}{l}\text { Compet } \\
\text { ence }\end{array}$ & $\begin{array}{l}\text { Industry } \\
\text { Interaction }\end{array}$ & $\begin{array}{l}\text { Course } \\
\text { Structure }\end{array}$ & $\begin{array}{l}\text { Internship } \\
\text { Output }\end{array}$ & $\begin{array}{l}\text { Entrepren } \\
\text { eurship }\end{array}$ & $\begin{array}{l}\text { Emplo } \\
\text { yabilit } \\
\text { y }\end{array}$ \\
\hline Tangibility & 1.000 & & & & & & & \\
\hline Reliability & 0.786 & 1.000 & & & & & & \\
\hline Competence & 0.678 & 0.743 & 1.000 & & & & & \\
\hline $\begin{array}{l}\text { Industry } \\
\text { Interaction }\end{array}$ & 0.765 & 0.712 & 0.678 & 1.000 & & & & \\
\hline $\begin{array}{l}\text { Course } \\
\text { Structure }\end{array}$ & 0.675 & 0.698 & 0.698 & 0.768 & 1.000 & & & \\
\hline $\begin{array}{l}\text { Internship } \\
\text { Output }\end{array}$ & 0.723 & 0.689 & 0.690 & 0.678 & 0.745 & 1.000 & & \\
\hline $\begin{array}{l}\text { Entrepreneurs } \\
\text { hip }\end{array}$ & 0.698 & 0.687 & 0.567 & 0.578 & 0.694 & 0.678 & 1.000 & \\
\hline Employability & 0.712 & 0.689 & 0.654 & 0.590 & 0.609 & 0.743 & 0.678 & 1.000 \\
\hline
\end{tabular}

All correlation is significant at the 0.01 level (2-tailed).

XII. Relative importance of the four dimensions

In order to determine the relative importance of the six dimensions in influencing customers' overall quality perceptions we regress the overall quality assessment scores on the service quality score for the individual dimensions. The results of such a regression analysis are shown in table- 6 . The adjusted $\mathrm{R}^{2}$ value is statistically significant, and similar to those obtained by (Parasuraman et al. 1988). The combined dimension, competence - personal interaction is most critical dimension for students. Physical aspect is the second most 
important dimension. A striking result in terms of the dimensions in predicting overall service quality is that course structure and employability are the least high important dimensions for management graduating students.

Table-6: Relative importance of the four dimensions in predicting overall service quality

\begin{tabular}{|l|c|c|c|}
\hline Dimensions & Standard Coefficient & $\begin{array}{l}\text { Significance } \\
\text { Level }\end{array}$ & \multirow{2}{*}{ Adjusted R } \\
\hline Tangibility & 0.450 & 0.000 & \multirow{2}{*}{$0.972(\mathrm{p}<0.000)$} \\
\hline Reliability & 0.467 & 0.000 & \multirow{2}{*}{} \\
\hline Competence & 0.439 & 0.000 & \multirow{2}{*}{0.000} \\
\cline { 1 - 3 } Industry Interaction & 0.475 & 0.000 & \\
\hline Course Structure & 0.431 & 0.000 & \\
\hline Internship Output & 0.445 & 0.000 & \\
\hline Entrepreneurship & 0.435 & 0.000 & \\
\hline Employability & 0.490 &
\end{tabular}

\section{Conclusions}

Delivering quality service has become an important goal for most universities and institutions of management education. This study represents an important starting point in the development of valid and reliable measures of universities' service quality. It contributes to the marketing and educational literature by introducing a new measure that provides both researchers and practitioners with more specific information concerning service quality's effect on students' satisfaction with universities services. In particular it suggests that university service quality can be measured with eight dimensions scale where employability and industry institute interaction is the most important factor for management graduating students. In practice, the importance of this dimension points to the need for stronger management emphasis on service dependability of personalized interest when interacting with graduate students. Although the results of this study provide valuable insight into relationship of student satisfaction with university/institute services, one obvious limitation is its external validity. Since this study is based on university department both public and private, institutions and autonomous institutions, the generalizability of findings can be established. The external validity of eight factors, this measure cannot be claimed until a series of follow-up studies are conducted in different universities/ institute settings. As competition for students has escalated among universities, student satisfaction has received increased attention. Since service quality and student satisfaction are important factors in retention and image building, it is important that institutes must focus on service quality (process) and use the tools of continuous improvement. Quality is what our customers tell us, it is not what we say it is. Progress can only be determined and improved by measurement (Coates, 1990). This study is an attempt to measure service quality in higher management education.

\section{References}

[1] Aldridge, S. \& Rowley, J. (1998) Measuring customer satisfaction in higher education, Quality Assurance in Education, 6(4), pp. 197-205.

[2] Anderson James C. And Gerbing David w., (1998) "Structural equation modeling in practice: A review and recommended two-step approach," Psychological bulletin, 103(May), 411-23.

[3] Asubonteng, P. et al. (1996) SERVQUAL revisited: a critical review of service quality, Journal of Services Marketing, 10(6), pp. 62-81.

[4] Avdjieva, M. \& Wilson, M. (2002) Exploring the development of quality in higher education, Managing Service Quality, 12(6), pp. $372-383$.

[5] Babakus, E. \& Mangold, W. G. (1992) Adapting SERVQUAL scale to hospital services: an empirical investigation, Health Services Research, 26, pp. 767-786.

[6] Berry, L. L. (1995) Relationship marketing of services - growing interest, emerging perspectives, Journal of the Academy of Marketing Science, 23(4), pp. 236-245.

[7] Buttle, F. (1996) SERVQUAL: review, critique, research agenda, European Journal of Marketing, 30(1), pp. 8-32.

[8] Bitner, M.J. (1992) Servicescapes: the impact of physical surroundings on customers and employees, Journal of Marketing, 56, pp. 57-71.

[9] Brennan, J. et al. (1992) Towards a Methodology for Comparative Qualitative Assessment in European Higher Education (London: CNAA, CHEPS, HIS).

[10] Brigham, S.E. (1993) Lessons we can learn from industry, Change, 25, pp. 42-46.

[11] Cheng, Y.C. \& Tam, W.M. (1997) Multi-models of quality in education, Quality Assurance in Education, 5(1), pp. 22-31.

[12] Coate, L.E. (1990) TQM on campus: implementing total quality management in a university setting, Business Officer, 24(5), pp. 26-35.

[13] Cronbach, L.J. (1951) Coefficient alpha and the internal structure of test, Psychometric, 16, pp. 297-300.

[14] Crosby, P.B. (1979) Quality is Free (New York: McGraw Hill).

[15] Cuthbert, P. F. (1996) managing service quality in HE: is SERVQUAL the answer? Managing Service Quality, 6(3), pp. 31-35.

[16] Dotchin, J.A. \& Oakland, J.S. (1994) TQM in services, Part I: understanding and classifying services, International Journal of Quality and Reliability Management, 11(3), pp. 9-26.

[17] Edwell, P. (1993) Total quality and academic practice, Change, May-June, pp. 58-64. 
[18] Feigenbaum, A.V. (1951) Quality Control: Principles, Practice and Administration (New York: McGraw-Hill).

[19] Ferguson, P.M. et al. (1999) External effectiveness of service management: a study of business-to-business relationships in Mexico, Canada and the USA, International Journal of Service Industry Management, 10(5), pp. 409-429.

[20] Firdaus, A. 2006. The development of HEdPERF: a new measuring instrument of service quality for higher education, International Journal of Consumer Studies 30(6): 569-581.

[21] Franceschini, F. \& Rossetto, S. (1995a) QFD: the problem of comparing technical-engineering design requirements, Research in Engineering Design, 7, pp. 270-278

[22] Galloway, R.L. \& Wearn, K. (1998) Determinants of quality perception in educational administration-potential conflict between the requirements of internal and external customers, Educational Management and Administration, 26(1), Sage Publications.

[23] Gaster, L. (1995) Quality in Public Services (Buckingham: Open University Press).

[24] Ghobadian, A. et al. (1994) Service quality: concepts and models, International Journal of Quality and Reliability Management, 11(9), pp. 43-66.

[25] Gilmore, H.L. (1974) Product conformance, Quality Progress, 7(5).

[26] Gronroos, C. (1984) A services quality model and its marketing implementations, European Journal of Marketing, 18(4), pp. 36-44.

[27] Gill, J. \& Johnson, P. (1991) Research Methods for Managers (London, UK: Paul Chapman).

[28] Hair, J. F. et al. (1998) Multivariate Data Analysis, 5th edn (Upper Saddle River, NJ: Prentice Hall).

[29] Hill, F. M. (1995) managing service quality in higher education: the role of the student as primary consumer, Quality Assurance in Education, 3(3), pp. 10-20.

[30] Juran, J.M. \& Gryna, F.M. Jr. (Eds) (1988) Juran's Quality Control Handbook (New York: McGraw-Hill).

[31] Kandampully, J. (1997) Firms should give loyalty before they can expect it from customers, Managing Service Quality, 7(2), pp. 92-94.

[32] Kanji, G. K. and Tambi, A. M. B. A. (1999) Total quality management in UK higher education institutions, Total Quality Management, 10(1), pp. 129-153.

[33] Lampley, J. H. (2001) Service quality in higher education: expectations versus experiences of doctoral students, College and University 77(2), pp. 9-14.

[34] Lau, L. K. (2003) Institutional factors affecting student retention, Education, 124(1), pp. 126-136.

[35] Lee, H. et al. (2000) The determinants of perceived service quality and its relationship with satisfaction, Journal of Services Marketing, 14(3), pp. 217-231.

[36] Lewis, B.R. \& Mitchell, V.W. (1990) Defining and measuring the quality of customer service, Marketing Intelligence and Planning, 8(6), pp. 11-17. Liaison Committee of Rectors' Conferences (1993) Quality Assessment in European University and Higher Education (Brussels).

[37] Long, P. et al. (1999) Measuring the satisfaction gap: education in the market place, Total Quality Management, 10(4/5), pp. 772778 .

[38] Malhotra, N. K. (1993) Marketing Research: An Applied Orientation (Englewood Cliffs, NJ: Prentice Hall).

[39] Maddux, G.A. et al. (1991) Organizations can apply QFD as strategic planning tool, Industrial Engineering, September.

[40] Masters, R.J. \& Leiker, L. (1992) Total Quality Management in higher education: applying Deming's fourteen points, College and University Personnel Association (CUPA), 43(2), pp. 27-31.

[41] Mazur, G.H. (1994) QFD outside North America - current practice in Europe, The Pacific Rim, South Africa and points beyond, Proceedings of the 6th Symposium on QFD, MI.

[42] Narasimhan, K. (1997) Improving teaching and learning: perceptions minus expectations gap analysis approach, Training for Quality, 5, pp. 121-125.

[43] Norman, G. R. \& Streiner, D. L. (1997) PDQ Statistics, 2nd edition (Missouri, USA: Mosby-Year Book)

[44] Nunnally, J.C. (1978) Psychometric Theory (New York: McGraw Hill).

[45] O'Neill, M. (2002) The influence of time on student perceptions of service quality: the need for longitudinal measures, Journal of Educational Administration, 41(3), pp. 310-324.

[46] Oldfield, B. M. \& Baron, S. (2000) Student perceptions of service quality in a UK university business and management faculty, Quality Assurance in Education, 8(2), pp. 85-94.

[47] Parasuraman, A. et al. (1988) SERVQUAL: a multiple item scale for measuring service quality, Journal of Retailing, 64(1), pp. 1240.

[48] Peters, T.J. \& Waterman, R.H. (1982) In Search of Excellence (New York: Harper \& Row).

[49] Pitman, G. et al. (1995) QFD application in an educational setting: a pilot field study, International Journal of Quality and Reliability Management, 12(6), MCB University Press.

[50] Rowley, J. (1997) Beyond service quality dimensions in higher education and towards a service contract, Quality Assurance in Education, 5(1), pp. 7-15.

[51] Reynolds, D. (1986) Academic Standards for Universities (London: CVCP).

[52] Sahney, S. et al. (2004) A Servqual and QFD approach for total quality education in the Indian context: a student perspective, International Journal of Productivity and Performance Management, Emerald, 53(2), pp. 143-166.

[53] Sallis, E. (1993) TQM in Education (London: Kogan Page).

[54] Sasser, W.R. Jr. \& Arbeit, S. (1978) Selling jobs in the service sector, Business Horizons, June, pp. 61-65.

[55] Saunders, I.W. \& Walker, M. (1991) TQM in tertiary education, International Journal of Quality and Reliability Management, 8(5), pp. 91-102.

[56] Sander, P. et al. (2000) University students' expectations of teaching, Studies in Higher Education, 25(2), pp. 309-323.

[57] Schmidt, R. (2002) A student's initial perception of value when selecting a college: an application of value added, Quality Assurance in Education, 10(1), 37-39.

[58] Shank, M. et al. (1995) Understanding professional service expectations: do we know what our students expect in a quality education?, Journal of Professional Services Marketing, 13, pp. 71-89.

[59] Sigala, M. 2004b. The ASP-Qual model: Measuring ASP service quality in Greece, Managing Service Quality 14(1): 103-114.

[60] Staropoli, A. (1992) The French Committee National D'evaluation; Quoted in Craft, A., (Ed.) (1991) Quality Assurance in Higher Education: Proceedings of an International Conference, Hong Kong (London: Falmer).

[61] Steiger, J.H. (1990) Structural model evaluation and modification: an interval estimation approach, Multivariate Behavioral Research, 25, pp. 173-180.

[62] Tang, K.H. \& Zairi, M. (1998) Benchmarking quality implementation in a service context: a comparative analysis of financial services and institutions of higher education - Part III, Total Quality Management, 9(8), pp. 666-679. 
[63] Tribus, M. (1994) TQM in education: the theory and how to put it to work, in: Quality Goes to School: Readings on Quality Management in Education (American Association of School Administrators, Arlington, VA), pp. 37-40.

[64] Walter, A. \& Gemunden, H.G. (2000) Bridging the gap between suppliers and customers through relationship promoters: theoretical considerations and empirical results, Journal of Business and Industrial Marketing, 15, pp. 86-105.

[65] Williams, G. (1990) Quality and resources allocation, in: C.P.J. Loder (Ed.) Quality Assurance and Accountability in Higher Education (London: Kogan Page).

[66] Winter, R.S. (1991) Overcoming barriers to Total Quality Management in colleges and universities, New Directions for Institutional Research, 18(3), pp. 53-62.

[67] Vidal, J. et al. (2003) Guidance services in Spanish universities, Tertiary Education and Management, 9(4), pp. 267-280.

[68] Zafiropoulos, C. (2006) Students' attitudes about Educational Service Quality, The Cyprus Journal of Sciences 4: 13-24

[69] Zeithaml, V. A.; Parasuraman, A. and Berry, L. L. (1986) SERVQUAL: a multi-item scale for measuring customer perception of service quality, Journal of Retailing Spring: 12-40. 